\title{
Medicinal Plants Used in Management of Various Mental Illnesses in Goma City, Democratic Republic of Congo
}

\author{
Samuel Kule Kyolo, Esther Katuura², Godfrey Bbosa1, John Odda', Norah Mwebaza1, \\ Zacharie Tsongo Kibendelwa ${ }^{3}$, Noeline Nakasujja ${ }^{4}$
}

\footnotetext{
${ }^{1}$ Department of Pharmacology and Therapeutics, School of Biomedical Sciences, College of Health Sciences, Mekerere University, Kampala, Uganda

${ }^{2}$ Department of Plant Sciences, Microbiology and Biotechnology, School of Biological Sciences, College of Natural Sciences, Makerere University Kampala, Uganda

${ }^{3}$ Department of Internal Medicine, Faculty of Human Medicine, University of Goma (UNIGOM), Democratic Republic of Congo

${ }^{4}$ Department of Psychiatry, School of Medicine, College of Health Sciences, Makerere University Kampala, Uganda Email: kyolosamuel@gmail.com
}

\begin{abstract}
How to cite this paper: Kyolo, S.K., Katuura, E., Bbosa, G., Odda, J., Mwebaza, N., Kibendelwa, Z.T. and Nakasujja, N. (2022) Medicinal Plants Used in Management of Various Mental Illnesses in Goma City, Democratic Republic of Congo. Neuroscience \& Medicine, 13, 17-42.

https://doi.org/10.4236/nm.2022.131002
\end{abstract}

Received: December 5, 2021

Accepted: February 22, 2022

Published: February 25, 2022

Copyright $\odot 2022$ by author(s) and Scientific Research Publishing Inc. This work is licensed under the Creative Commons Attribution International License (CC BY 4.0).

http://creativecommons.org/licenses/by/4.0/

\section{(c) (i) Open Access}

\begin{abstract}
Many mentally ill people in Goma city, Democratic Republic of Congo (DRC), seek treatment from Traditional Health Practitioners (THPs) that utilize medicinal plants (MPs) in management of various ailments. The study aimed to document the MPs used locally to manage mental illnesses (MIs). An indepth ethnobotanical survey including 43 respondents selected using snow ball method and interviewed using semi-structured questionnaires was conducted in Goma city, in DRC, from May to September 2021. Voucher specimens were collected from the study area and identified at Makerere University Herbarium (MHU). Data were analyzed using ethnobotanical parameters, frequency index, Rahman's similarity index (RSI) and non-parametric tests as well as Spearman correlation coefficient. A total of 30 plant species, represented amongst 29 genera and 19 families were reportedly used to treat MIs. Of these $63.33 \%$ were reported for anxiety, $36.67 \%$ for psychosis and $30 \%$ for depression. Most abundant taxa were reported for three families including Asteraceae, Lamiaceae and Solanaceae. Among MPs used in Goma city, the two priority plant species for anxiety were Euphorbia abyssinica and Cleome gynandra $L$. While, the two priority plant species for depression were Conyza sumatrensis and Emilia coccinea. High similarity (RSI $=77.42 \%)$ was observed in the use of common species for MIs between THPs from both Goma and Karisimbi communes. Results prove that local people of Goma city use MPs species against MIs that could be further studied for pharmacological
\end{abstract}


effectiveness and safety.

\section{Keywords}

Medicinal Plants, Indigenous Management, Mental Illnesses

\section{Introduction}

Mental illnesses (MIs) are a common problem that affects the thinking ability, emotion or behavior of the affected individuals [1]. Globally, the prevalence of mental disorders (depression, anxiety, post-traumatic stress disorder, bipolar disorder, and schizophrenia) was reported by the World Health Organization (WHO) in 2019 to be $22.1 \%$ in the conflict-affected populations [2].

In some African countries such as Somalia, the prevalence of MIs in regions affected by conflict has been reported to be even higher at $33 \%$ compared to those of countries less affected by conflicts such as Uganda and Tanzania which were reported to be $4.6 \%$ and 5.3\% respectively [3] [4] [5]. Regarding the Democratic Republic of Congo [6] [7] [8], the prevalence of MIs, especially depression and anxiety was reported at $22 \%$ and $13 \%-23 \%$ in provinces affected by war conflicts such as North Kivu (NK) province including Goma city, higher than other provinces of the country. The contributing factors are wars, poverty, use of psychoactive substances and sexual abuse [9]. The local culture, poor health facilities, among many others are reported to have exacerbated the high prevalence of MIs in DRC [6] [10] [11].

Communities in war or conflict zones such as the Eastern part of DRC, are more often exposed to threatening events such as hearing or witnessing human killings, bombardments, gunfire attacks, massacres, mutilations, rapes, tortures and house to house raids and these exacerbate the incidence of MIs [12]. People living in that part of the country have been forced to leave their hometowns, villages, occupations, assets and thereafter condemned to live without income or in abject poverty [13].

The problem has been further aggravated by poverty caused by war and the fact that there are no budgetary allocations for mental health in DRC [6]. The primary funding of these people to meet their healthcare needs mainly comes in the form of out-of-pocket expenditure by the patient or patient's family. Thus, the cost of psychiatric treatment among the victims is very high in relation to average earnings [6]. Hence, conventional medicines used in the management of MIs are costly to many people in DRC [10].

War conflicts have also resulted in redundancy especially of the youth who are more prone to psychoactive substance abuse. Whereby DRC has been reported to be the biggest producer of Cannabis sativa that is associated with psychosis [14]. The psychophysiological effects of the drug, and the economic role of the trade have been linked to the financing of various armed groups hence increas- 
ing violence associated to MIs in NK Province. Also the poor infrastructure especially the poor mental healthcare facilities, deficiency of mental healthcare workforce and services worsens the situation. In addition to the mental healthcare infrastructure and medical specialists being very centralized in Kinshasa, the capital; and a few other provinces [6], thus leaving a great area of DRC lacking mental healthcare infrastructure. Currently, there are 102 neuropsychiatrists for a population of over 66 million people, of whom only one is in the province of NK, one is in Lubumbashi and 100 are in Kinshasa [15].

Culture influences many Congolese people who believe that MIs are a result of curses or punishment from God and cannot be treated professionally [6]. They also believe in supernatural power, prayers and MPs that may not be scientifically proven [6]. Thus, religious faith practices or spiritual healing and THPs who use MPs that are richly accessible and supernatural power to manage illnesses have continued to play an essential role in management of MIs among the affected individuals [16]. These entire factors, make people delay in seeking mental healthcare services where they exist thus worsening the conditions or resorting to use of alternatives including the MPs.

The country is also rich in natural forests with various MPs that are used by THPs in management of MIs in their local communities. It has been reported that DRC has 135 million hectares of natural forests that have boundless biodiversity including MPs that may have psychoactive properties [17]. According to Edgerton [18], there are a number of MPs used among African communities in the management of patients with MIs. According to him, some of these patients managed by these THPs using MPs have been reported to recover more rapidly and fully than do individuals who use conventional medicine. It has been reported that in DRC, in most cases of MIs, THPs are often the only source of healthcare services to the affected individuals [10]. However, these claims are not fully documented as well as scientifically evaluated. There is limited information on the methods used by THPs in the management of MIs among the sufferers in Goma city, especially the MPs. The study documented plants used in traditional treatment of MIs, associated indigenous knowledge and prioritized two plants for anxiety and depressive disorders considered most effective. Indeed, anxiety and depressive disorders have both been reported by WHO [4] to be the commonest MIs in regions affected by conflict such as NK province in DRC.

\section{Materials and Methods}

\subsection{Study Design}

It was community based cross-sectional study that involved an in-depth ethnobotanical survey. Both quantitative and qualitative study designs were carried out using a semi-structured in-depth interview.

\subsection{Study Area}

The study was carried out in Goma city, capital of NK province in eastern DRC. 
Based on its geographic coordinates, Goma is located between 1041'S latitude (-1.6771 degrees minutes) and 29,015'E longitude (29.242 degrees minutes) [19]. Its altitude is estimated at about $1500 \mathrm{~m}$ above sea level and has an area of 66.45 $\mathrm{km}^{2}$ covered by volcanic rock with undulated reliefs at about $18 \mathrm{~km}$ from Nyiragongo volcano [20]. The area is characterized by savanna tropical climate influenced by high altitude. The annual minimal and maximal average temperatures, as well as annual amount of precipitation are $14.03^{\circ} \mathrm{C}, 25.5^{\circ} \mathrm{C}$ and 1257 $\mathrm{mm}$ respectively. Overall, the city has a multi tribal population of 1.1 million urban habitants [21].

Regarding administrative organization, Goma city includes two communes; commune of Goma and commune of Karisimbi subdivided into 7 and 11 quarters respectively (Figure 1). Each quarter is subdivided into cells with several streets. The commune of Goma is located in the south of Goma city and has an area of $28.754 \mathrm{~km}^{2}$. It hosts almost all political administrative and economical quarters. While the commune of Karisimbi is located in the north of commune of Goma and has an area of $37.698 \mathrm{~km}^{2}$. The commune is essentially residential and has population of 622,105 habitants with low income [20]. So, individuals from Karisimbi were used as key informants to select THP key informants.

Data on indigenous use of MP in management of MIs and related symptoms was collected in two communes for some reasons, including: 1) Their location near Virunga National Park rich in biodiversity; 2) Goma city has been the theater of war for more than 20 years that has disorganized government general health care [22]; 3) Several studies conducted in Goma city have reported the use of herbal medicines. Overall, among previous studies done on herbal medicine in Goma city none cover specifically MIs and related symptoms.

\subsection{Simple Size and Sampling Procedure}

The sample size was determined using a single proportion formula, $n_{1}=Z^{2} p(1-p) / d^{2}$,



Figure 1. Map of the Democratic Republic of Congo showing Goma, North Kivu, adapted from Agence France-Presse (AFP) [23] and map [20] showing Goma City. Focus of the study: Commune of Goma and commune of Kasirimbi. 
where $n_{1}$ was the initial sample size $\left(n_{1}=376.48\right)$, considering a confidence level of $95 \%$, an overall proportion of good knowledge of population of Goma city about THP dealing with MIs of 50\% estimated on basis of pilot study [24], and a precision of $5 \%$.

We performed a finite population correction, $n_{2}=n_{1} / 1+\left(n_{1} / N\right)$, where $N$ was the total number of a targeted population including male and female respondents aged 18 years and above, non THPs and non-healthcare practitioners (HCP) of commune of Karisimbi. Thus, we computed N = 343,278 according to INSNorth-Kivu [20] and we obtained $n_{2}=376.07$. Multiplying $n_{2}$ by 1.5 to account for the clustering effect, and adding a $15 \%$ non-response rate, we obtained a final sample size of 620 key informants.

Sampling procedure of the key informants included geographical cluster and stratified random methods. Age-order method was used to identify the potential respondents in households [25], and no replacement was made. The key informants consenting to the objective of the study were used to select THPs dealing with MIs in Goma city.

We defined a THP according to the Congolese [26] law on traditional medicine(TM). It has been reported that among THPs, herbal therapists are reputed to have in-depth knowledge on local plants. However, each of them has its own field of expertise and the techniques as well as MPs employed in management of various ailments differ considerably [27]. Thus, snowball ball sampling method was used to select male and female THP dealing with MIs and consenting to participate in the study.

Also, it has been reported that in qualitative study, data collection is based upon a saturation point judged by researcher to give best information [28]. Thus, sample size of THP key informants included total number of all those who were appointed by the 620 key informants as dealing with management of MIs in Goma city.

\subsection{Data Collection}

Firstly, permission to collect data from individuals in Goma city was got from the Directorate of Health Services. Secondly, permission was got from administrative leaders before any interaction with prospective respondents. Thereafter researcher interacted with prospected respondent following two steps; especially: 1) Interaction with each selected 620 key informants to select THP key informants; 2) Interaction with each THP key-informant for in-depth ethnobotanical survey. Overall, researcher started their interaction with each prospective respondent by first explaining the aims and objectives of the project in order to solicit their consent and cooperation before any data were gathered. We used faceto-face interview to interact with all respondents recruited in the study. Then, voucher specimens were collected, identified and allocated a number by a taxonomist at Makerere University National Herbarium (MHU), Kampala.

Regarding data collection tools, for quantitative study, data related to 620 res- 
pondents in local communities were collected through face-to-face semi-structured in-depth interview by using interview schedule translated into French and local language (Kiswahili). The interview schedule included 2 domains especially socio-demographic and knowledge of THP experts in management of MIs in Goma city. For qualitative study, data from THPs were collected through an interview guide translated into French and local language (Kiswahili). The interview guide related to THPs had 5 themes including, socio-demographic theme, MPs used in management of MIs (plant name, part of plant used, treated MIs, method of preparation, route of administration, tratment duration), method of diagnostic, how to recognize healed patient and source of knowledge.

\subsection{Selection Criteria of Study Participants}

Both adult male and female individuals aged between 18 years and above, non THPs and non allopatic health care practitioners, residents of Karisimbi commune and consenting to participate in the study were recruited in the study. The recruited individuals were aked to nominate THPs dealing with management of MIs in Goma city. Both male and female THPs appointed by individual in community as dealing with management of MIs, resident within Goma city and consenting to participate in the study were selected for interview. Individuals and THPs who were below 18 of age, did not consent to the study, and those who were absent at the time of data collection were excluded from the study.

\section{Data Analysis}

\subsection{Quantitative Data Processing}

Excel 2016 was used to process the data. Quantitative raw data were cleaned scrutinizing the completed research instruments to identify and minimize, as far as possible, errors, incompleteness, misclassification and gaps in the information obtained from the respondents. Having cleaned, the data were coded following the process including developing code book, pretesting the code book, coding the data and verifying coded data. The data base information necessary to answer our research questions were exported to SPSS 2017 statistical package for analysis.

\subsection{Qualitative Data Processing and Analysis}

Qualitative transcribed data using Microsoft Word 2018 were closely studied according to the following steps: 1) Identifying the main themes communicated by respondent; 2) Assigning codes to the main themes; 3) Classifying responses under the main themes; 4) Transformation of qualitative data into quantitative data for analysis of responses of main themes.

\subsection{Ethnobotanical Parameters Measured}

Use value (UV) parameter was calculated according to the formula of Phillips et al. [29] and Thomas et al. [30] to determine the relative importance attached to a given MPs species in TM of Goma. 


$$
\mathrm{UVs}=\frac{\sum_{i=1}^{n} \mathrm{Uis}}{\mathrm{ns}}
$$

In which UVs is the use value of a given species s; Uis is the number of uses of species mentioned by informant $i$; ns is the total number of informants.

Since it has been reported that UVs parameter does not reflect the consensus of informants on MPs use, we also calculated for each species, the parameter informant agreement ratio (IAR) [31] [32] [33].

$$
\mathrm{IAR}=\frac{\mathrm{Nr}-\mathrm{Na}}{\mathrm{Nr}-1}
$$

In which $\mathrm{Nr}$ is the total number of citations of the species and $\mathrm{Na}$ is the number of diseases treated by the species.

Informant consensus factor (ICF) was calculated for each plant use according to Trotter and Logan formula [31], to verify informant agreement for a plant species in the treatment of a particular MI and to select species with an interesting therapeutic potential for phytochemical and pharmacological studies.

$$
\mathrm{ICF}=\frac{\mathrm{Nuc}-\mathrm{Nt}}{\mathrm{Nuc}-1}
$$

In which Nuc is the number of citations of a particular MI; Nt is the number of species used for the treatment of that MI.

Species therapeutic potential (STP) parameter was calculated according to Heinrich [34] to select plant species that seemed to be potentially effective for treating MIs and therefore merit phytochemical, pharmacological and toxicity studies. We considered species with high STP\% as potentially effective.

$$
\mathrm{STP} \%=\frac{\mathrm{Ni}-1}{\mathrm{Nti}}
$$

In which $\mathrm{Ni}$ is the number of informants who mentioned the use of a species for the treatment of a given MI, and Nti is the total number of informants who mentioned any species for the treatment of that MI.

Medicinal plants were considered as priority for a MI if they had the highest UV, IAR, and STP\% values, also, if not much was known about their anxiolytic and antidepressant activities as well as toxicity profile in laboratory animal models.

\subsection{Quantitative Data Relative to MPs Use and Traditional Medicine Knowledge Analysis}

Quantitative data from both quantitative and qualitative studies were expressed as frequency, displayed in tables and graphs. Non parametric tests including Mann-Whitney [35] and Kruskal-Wallis [36] were performed to assess whether or not significance difference exists in MP knowledge between the two genders, and different religion groups. The correlation coefficient of Spearman was calculated to elucidate if there were a correlation between informants' age, experience, source of knowledge, education level and their knowledge on MPs. Results of Mann-Whitney, Kruskal-Wallis and Spearman correlation tests were considered 
as statistically significant for $\mathrm{p}$ values $<0.05$.

To find out the percentage of common use of plants species for MIs treatment between THPs of commune of Goma and THPs of commune of Karisimbi, the Rahman's similarity index (RSI) was used, which indicates the similarity of species used for treating the same MIs [37]. Thus, THPs of the two communes are closer in treatment of MIs if they use the same species in their management; hence, RSI > 50\%.

$$
\mathrm{RSI}=\frac{d}{|a+b+c-d|}
$$

In which " $a$ " is the number of unique species in commune of Goma, " $b$ " is the number of unique species in commune of Karisimbi, " $c$ " is the number of common species in both communes Goma and Karisimbi, and " $d$ " is the number of common species in both Goma and Karisimbi that are used to treat the same disease; $a$ and $b \neq 0$ and $c$ and $d \geq 0$.

Also, Frequency index was used to find out the commonality of plant species. A plant species was considered as common when its FI was $>50 \%$.

\section{Result}

\subsection{Key Informant Profiles}

Socio-economic and demographic characteristics of respondents are sammurized in Table 1.

\subsection{Taxonomic Diversity}

A total of 30 plant species, distributed in 29 genera and 19 families were inventoried. Families representing most species were Asteraceae, Lamiaceae and Solanaceae (4 species i.e., 13.80\%). While the other 16 families were represented by 1 or 2 species (Table 2 ).

\subsection{Indigenous MPs Use in Management of MIs}

From total number of 30 plants species, 19 (63.33\%) were reported for anxiety and related symptoms, 11 (36.67\%) were reported for psychosis and $9(30 \%)$ were reported for depression (Figure 2). Leaves (90\%), decoction (46.67\%), oral ingestion $(73.33 \%)$, wild $(53.33 \%),<1$ month $(73.33 \%)$, were the most frequently cited plant part, method of preparation, mode of administration, place of collection and treatment duration respectively (Figure 2).

None of 30 MPs was reported with the majority (FI $<50 \%$ ) of respondents (Table 2). However, high similarity $($ RSI $=77.42 \%)$ was observed in the use of common species for MIs between THPs key informants from both Goma and Karisimbi communes.

\subsection{Ethnobotanical Data Analysis}

\subsubsection{Relative Importance of a Given Plant (UVS, IAR)}

Medicinal plant use values ranged from 0.13 to 0.63 for plants used to treat anxiety. 
Table 1. Socio-economic demographic characteristics of respondents.

\begin{tabular}{|c|c|c|c|c|}
\hline \multirow[t]{2}{*}{ Variable } & \multicolumn{2}{|c|}{$\begin{array}{c}\text { Respondents non THP or } \\
\text { Non HCP }\end{array}$} & \multicolumn{2}{|c|}{ THP } \\
\hline & Respondents & $\%$ & Respondents & $\%$ \\
\hline \multicolumn{5}{|l|}{ Age } \\
\hline $18-27$ & 157 & 25.28 & 02 & 4.65 \\
\hline $28-36$ & 199 & 32.04 & 12 & 27.91 \\
\hline $37-46$ & 149 & 23.99 & 13 & 30.23 \\
\hline $47-55$ & 79 & 12.72 & 10 & 23.26 \\
\hline $56-64$ & 32 & 5.15 & 04 & 9.30 \\
\hline No response & 05 & 0.80 & 0 & 0.00 \\
\hline \multicolumn{5}{|l|}{ Gender } \\
\hline Male & 307 & 49.44 & 28 & 65.12 \\
\hline Female & 314 & 50.56 & 15 & 34.88 \\
\hline \multicolumn{5}{|l|}{ Education level } \\
\hline O level & 01 & 0.16 & 0 & 0.00 \\
\hline Primary school & 97 & 15.61 & 0 & 0.00 \\
\hline Secondary school & 315 & 50.72 & 29 & 67.44 \\
\hline University & 89 & 14.33 & 14 & 32.56 \\
\hline None & 119 & 19.16 & 0 & 0.00 \\
\hline \multicolumn{5}{|l|}{ Occupation/Profession } \\
\hline Businessman & 226 & 36.39 & - & - \\
\hline Government employee & 25 & 4.02 & - & - \\
\hline Farmer & 04 & 0.64 & - & - \\
\hline Medical Doctor & - & - & - & - \\
\hline Nurse & - & - & - & - \\
\hline Peasant & 211 & 33.98 & - & - \\
\hline Others & 1155 & 24.96 & - & - \\
\hline \multicolumn{5}{|l|}{ Residence } \\
\hline Goma & 0 & 0 & 09 & 20.93 \\
\hline Karisimbi & 100 & 100 & 34 & 79.07 \\
\hline \multicolumn{5}{|l|}{ Religion } \\
\hline Catholic & 191 & 30.76 & 16 & 37.21 \\
\hline Protestant & 318 & 51.21 & 20 & 46.51 \\
\hline Muslim & 61 & 9.82 & 03 & 6.98 \\
\hline Traditionalist & 13 & 2.09 & 02 & 4.65 \\
\hline
\end{tabular}




\begin{tabular}{|c|c|c|c|c|}
\hline \multicolumn{5}{|l|}{ Continued } \\
\hline Others & 38 & 6.12 & 02 & 4.65 \\
\hline \multicolumn{5}{|l|}{ TH status } \\
\hline Divine diagnostician & - & - & 0 & 0.00 \\
\hline Herbalist & - & - & 43 & 100 \\
\hline Other & - & - & 0 & 0 \\
\hline \multicolumn{5}{|c|}{ Experience in traditional medicine } \\
\hline$<5$ years & - & - & 05 & 11.63 \\
\hline$>5$ years & - & - & 35 & 81.39 \\
\hline No response & - & - & 03 & 6.98 \\
\hline
\end{tabular}

Legend: THP: Traditional health practitioner, -: No applicable. $n=621$ for respondents no THP and $n=43$ for THPs

Table 2. Family, number of species, scientific and local name, voucher number, medicinal use, frequency index (FI) and psychopharmacological scientific studies of MPs in the study area.

\begin{tabular}{|c|c|c|c|c|c|c|c|}
\hline Family & $\begin{array}{l}\text { Number } \\
\text { of } \\
\text { species }\end{array}$ & $\begin{array}{l}\text { Plant scientific and } \\
\text { local name }\end{array}$ & $\begin{array}{l}\text { Voucher } \\
\text { number }\end{array}$ & MI treated & $\begin{array}{l}\text { Other ethno } \\
\text { medicinal } \\
\text { applications }\end{array}$ & FI (\%) & $\begin{array}{l}\text { Scientific studies on the } \\
\text { plant against MI }\end{array}$ \\
\hline \multirow[t]{4}{*}{ Asteraceae } & 4 & $\begin{array}{l}\text { Bidens pilosa L., } \\
\text { Kashisha }^{\mathrm{BD}, 1, \mathrm{~N}, \mathrm{~W}}\end{array}$ & HBKY06 & Anxiety & $\begin{array}{l}\text { Convulsion, } \\
\text { gastritis, } \\
\text { poisoning }\end{array}$ & 9.30 & $\begin{array}{l}\text { Encyclopedia of Biodiversity } \\
\text { (Second Edition) [54] }\end{array}$ \\
\hline & & $\begin{array}{l}\text { Ageratum conyzoides } \\
\text { (L.) L., } \\
\text { Nalubanda }{ }^{\mathrm{N}, \mathrm{OC}, 1, \mathrm{~W}}\end{array}$ & HBKY26 & $\begin{array}{l}\text { Psychosis, } \\
\text { anxiety }\end{array}$ & $\begin{array}{l}\text { Vomiting, } \\
\text { Headache }\end{array}$ & 18.60 & $\begin{array}{l}\text { Anxiolytic potential of } \\
\text { methanol extract from } \\
\text { Ageratum conyzoides Linn } \\
\text { leaves [55] }\end{array}$ \\
\hline & & $\begin{array}{l}\text { Conyza sumatrensis } \\
\text { (Retz) E.Walker, } \\
\text { Kavingande }^{\mathrm{N}, \mathrm{O}, \mathrm{OC}, \mathrm{l}, \mathrm{W}}\end{array}$ & HBKY02 & Depression & Headache & 18.60 & - \\
\hline & & $\begin{array}{l}\text { Emilia coccinea (Sims) } \\
\text { G.Don., Majani ya } \\
\text { Sungura }^{\mathrm{O}, 1, \mathrm{~W}}\end{array}$ & HBKY 15 & Depression & $\begin{array}{l}\text { Colic, } \\
\text { infection of } \\
\text { urinary } \\
\text { tractus }\end{array}$ & 16.28 & - \\
\hline \multirow[t]{3}{*}{ Lamiaceae } & 4 & $\begin{array}{l}\text { Salvia sclarea L, Sauge } \\
\text { sclarée. }^{\mathrm{O}, 1, \mathrm{~W}}\end{array}$ & HBKY04 & Depression & Overwork & 4.65 & $\begin{array}{l}\text { Antidepressant-like effect of } \\
\text { Salvia sclarea is explained by } \\
\text { modulation of dopamine } \\
\text { activities in rats [56] }\end{array}$ \\
\hline & & $\begin{array}{l}\text { Ocimum basilicum L., } \\
\text { Basilic }^{\mathrm{O}, 1, \mathrm{~V}}\end{array}$ & HBKY01 & Depression & $\begin{array}{l}\text { Headache, } \\
\text { hypertermia }\end{array}$ & 17.28 & $\begin{array}{l}\text { The antidepressant-like effect } \\
\text { of Ocimum basilicum in an } \\
\text { animal model of depression } \\
\text { [57] }\end{array}$ \\
\hline & & $\begin{array}{l}\text { Mentha spicata L., } \\
\text { Menthe } \mathrm{e}^{\mathrm{O}, 1, \mathrm{~V}}\end{array}$ & HBKY16 & Depression & Flu, gastritis & 13.95 & $\begin{array}{l}\text { The antidepressant-like effect } \\
\text { of Mentha spicata 15essential } \\
\text { oil in animal models of } \\
\text { depression in male mice [58] }\end{array}$ \\
\hline
\end{tabular}




\section{Continued}

Salvia rosmarinus

Spenn, Romarin ${ }^{\mathrm{O}, 1, \mathrm{~V}}$

HBKY17 Depression Overwork

Solanaceae $\quad 4$

Fabaceae

2

Mimosaceae 2

Zingiberaceae $\quad 1$

Nymphaeaceae 1

Datura stramonium L., HBKY05 Psychosis, Convuslion kiyaka ${ }^{\mathrm{O}, 1,2, \mathrm{~W}}$ anxiety

Capsicum annuum L., HBKY29 Anxiety Ovusewe $\mathrm{N}^{\mathrm{N}, \mathrm{O}, 1, \mathrm{C}}$

Convulsion

Lycopersicum esculentum Mill., Tomatoe $\mathrm{OC}, \mathrm{N}, \mathrm{O}, \mathrm{l}, \mathrm{C}^{-}$

HBKY11 Depression Headache
Solanum

macrocarpon,

Nyanya $^{\mathrm{N}, \mathrm{OC}, \mathrm{O}, 1, \mathrm{C}}$

Desmodium
adscendens (Sw.) DC Ituza $^{\mathrm{O}, \mathrm{w}} \mathrm{W}$
Arachis hypogea L.,
Kalanga majani ${ }^{\mathrm{O}, \mathrm{l}, \mathrm{C}}$

Albisia lebbeck L., Musevere ${ }^{\mathrm{O}, 3, \mathrm{C}}$

Akasia sieberiana DC, Mugenge $\mathrm{O}^{\mathrm{O}, \mathrm{C}} \mathrm{C}$

Aframomum melegueta K.Schum, Ndehe $\mathrm{O}^{\mathrm{1}, \mathrm{W}}$

Nymphea lotus L., Nénuphar ${ }^{\mathrm{O}, \mathrm{1}, \mathrm{W}}$
HBKY22 Anxiety

Convulsion

palpitation,

diabetes

HBKY28 Anxiety, psychosis

Convulsion

HBKY12 Anxiety, psychosis

Constipation, 27.91 insomnia

HBKY18 Psychosis Vomiting

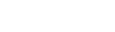

Convulsion psychosis

HBKY03 Anxiety

Tachycardia, convulsion

HBKY07 Psychosis, Insomnia anxiety
2.33

2.33

23.26

Antidepressant-like effect of ursolic acid isolated from Rosmarinus officinalis $\mathrm{L}$. in mice: evidence for the involvement of the dopaminergic system [59]

Evaluation of anti-anxiety activity of $D$. Stramonium seeds in mice [60]

Pharmacological validation of the anxiolytic, muscle relaxant and sedative like activities of C. annuum in animal model [61]

2.33 Trigonelline through the Attenuation of Oxidative Stress Exerts Antidepressantand Anxiolytic-Like Effects in a Mouse Model of Maternal Separation Stress [62]

$30.23-$

Neuropsychopharmacological 34.88 evaluation of Kalyanakam (an Ayuvervedic formulation in Suiss albino mice [63]

Sedative effects of Arachis hypogaea L. stem and leaf extracts on sleep deprived rats [64]

2.33 Neuropharmacological Activities of Methanol Extract of A. lebbeck (L.) [65]

30.23 Medicinal plants used for neuropsychiatric disorders treatment in the hauts bassins region of Burkina Faso [66]

11.62 Anti-stress potential of aqueous seed extract of $A$. melegueta [67]

9.30 Evaluation of anxiolytic and antidepressant-like activity of aqueous leaf extract of $N$. lotus [68] 
Continued

\begin{tabular}{|c|c|c|c|c|c|c|c|}
\hline Bignoniaceae & 1 & $\begin{array}{l}\text { Spathodea } \\
\text { campanulata } \mathrm{P} . \\
\text { Beauv., Mbina } \\
\text { O,3,W }\end{array}$ & HBКY20 & Anxiety & Convulsion & 4.65 & $\begin{array}{l}\text { Methanol extract of } S \text {. } \\
\text { campanulata P.(Beauv.) leaves } \\
\text { demonstrate sedative and } \\
\text { anxiolytic like actions on } \\
\text { Swiss albino mice [69] }\end{array}$ \\
\hline Apiaceae & 1 & $\begin{array}{l}\text { Petroselinum crispum } \\
\text { (Mill.) Fuss, Percil }^{\mathrm{O}, 1, \mathrm{~V}}\end{array}$ & НBКY19 & Depression & Headache & 2.33 & - \\
\hline Dioscoreaceae & 1 & $\begin{array}{l}\text { Dioscorea alata L., } \\
\text { Kisumbu }^{\mathrm{O}, 1,5, \mathrm{C}}\end{array}$ & HBКY23 & $\begin{array}{l}\text { Anxiety } \\
\text { Psychosis }\end{array}$ & Convulsion & 4.65 & $\begin{array}{l}\text { New insight in } \\
\text { neuropharmacological } \\
\text { activities of } D \text {. alata [70] }\end{array}$ \\
\hline Passifloraceae & 1 & $\begin{array}{l}\text { Passiflora edulis Sims, } \\
\text { Maracuja }^{\mathrm{O}, 1, \mathrm{C}}\end{array}$ & HBKY 14 & Anxiety & Insomnia & 18.60 & $\begin{array}{l}\text { Anxiolytic and sedative } \\
\text { activities of } P \text {. edulis } \mathrm{f} \text {. } \\
\text { flavicarpa [71] }\end{array}$ \\
\hline Acanthaceae & 1 & $\begin{array}{l}\text { Asystasia gangetica L., } \\
\text { Irungo }^{\mathrm{O}, \mathrm{OC}, 1, \mathrm{~W}}\end{array}$ & HBKY21 & Anxiety & Palpitation & 2.33 & $\begin{array}{l}\text { Medicinal plants with } \\
\text { reported anxiolytic and } \\
\text { sedative activities in Nigeria: } \\
\text { A systematic review [72] }\end{array}$ \\
\hline Amaranthaceae & 1 & $\begin{array}{l}\text { Celosia trigyna L., } \\
\text { Mfungu }^{\mathrm{OC}, \mathrm{N}, \mathrm{O}, 1, \mathrm{~W}}\end{array}$ & HBКY30 & Anxiety & $\begin{array}{l}\text { Anemia, } \\
\text { meningitis }\end{array}$ & 11.63 & - \\
\hline Capparaceae & 1 & $\begin{array}{l}\text { Cleome gynandra L., } \\
\text { Mgagani }^{\mathrm{OC}, \mathrm{N}, \mathrm{O}, \mathrm{l}, \mathrm{W}}\end{array}$ & HBKY27 & $\begin{array}{l}\text { Psychosis, } \\
\text { anxiety }\end{array}$ & $\begin{array}{l}\text { Headache, } \\
\text { dizziness }\end{array}$ & 34.88 & - \\
\hline Phytolaccaceae & 1 & $\begin{array}{l}\text { Phytolacca americana } \\
\text { Kihokolo }^{\text {OC,1,W }}\end{array}$ & HBKY08 & Psychosis & Detergent & 11.63 & - \\
\hline Urticaceae & 1 & $\begin{array}{l}\text { Cecropia concolor, } \\
\text { Kyungu }^{\mathrm{O}, 3, \mathrm{~W}}\end{array}$ & HBKY25 & Anxiety & $\begin{array}{l}\text { Palpitation, } \\
\text { cough }\end{array}$ & 2.33 & - \\
\hline Rubiaceae & 1 & $\begin{array}{l}\text { Morinda morindoides } \\
\text { (Baker) Milne-Redh, } \\
\text { Kongo Bololo }^{\mathrm{O}, \mathrm{V}, \mathrm{V}}\end{array}$ & HBKY13 & Depression & $\begin{array}{l}\text { Hypethermia, } \\
\text { neuropathy }\end{array}$ & 13.95 & - \\
\hline Euphorbiaceae & 1 & $\begin{array}{l}\text { Euphorbia abyssinica } \\
\text { (J.F.Gmel), Kiduha }^{\mathrm{O}, 1, \mathrm{C}}\end{array}$ & HBKY10 & $\begin{array}{l}\text { Anxiety, } \\
\text { psychosis }\end{array}$ & $\begin{array}{l}\text { Covulsion, } \\
\text { Parkinson } \\
\text { disease }\end{array}$ & 37.21 & - \\
\hline Vitaceae & 1 & $\begin{array}{l}\text { Cissus rubiginosa } \\
\text { (Welw. ex Baker) } \\
\text { Planch, Kayuzi }{ }^{\mathrm{O}, \mathrm{w}} \text { }\end{array}$ & HBКY24 & Anxiety & Diarrhea & 27.91 & - \\
\hline
\end{tabular}

FI: Frequency index; O: Oral; R: Rectal; BD: Bath of all body; N: Nasal; OC: Ocular; 1: Leave; 2: Seed; 3: Bark; 4: Flower; 5: Root; W: Wild; V: Vendor; C: Cultivated; $\mathrm{n}=43 \mathrm{THPs}$ key informants.

The most important MPs for treatment of anxiety in TM of Goma city Pharmacopeia were Euphorbia abyssinica, Desmodium adscendens (Sw), Cleome gynandra L. and Solanum macrocarpon with UVs > 0.5 (Figure 3(a)). However, UVs ranged from 0.14 to 0.19 for the plants used to treat depression. The most important MPs for treatment of depression in TM of Goma city Pharmacopeia were Conyza sumatrensis, Emilia coccinea (Sims) and Ocimum basilicum with UVs (>0.15) (Figure 3(d)). 


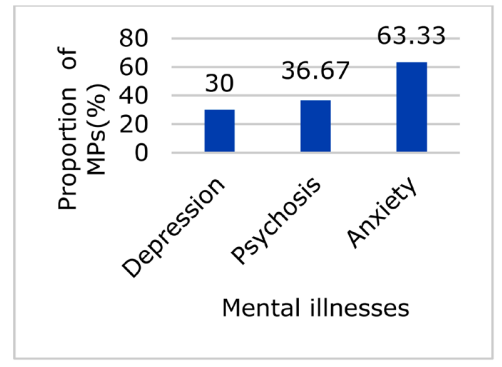

(a)

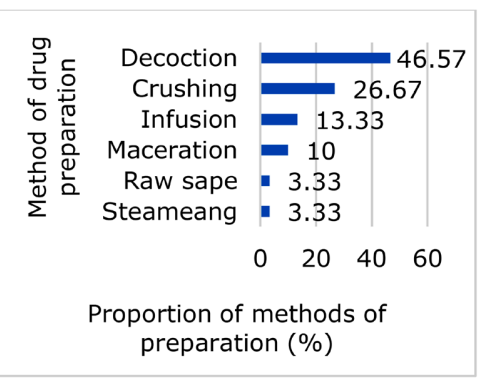

(d)

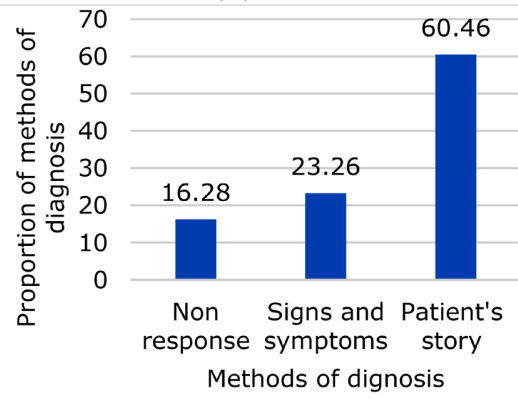

(g)

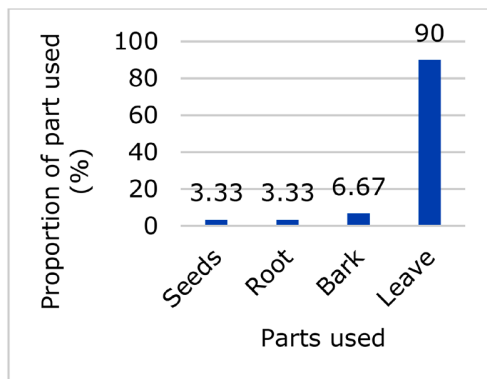

(b)

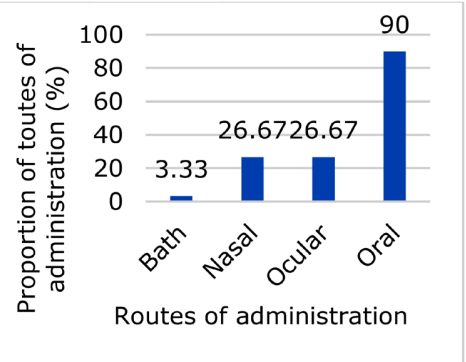

(e)

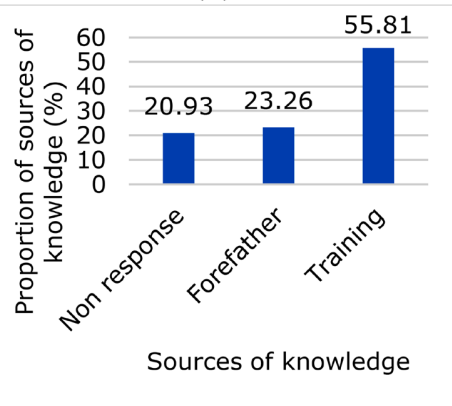

(h)

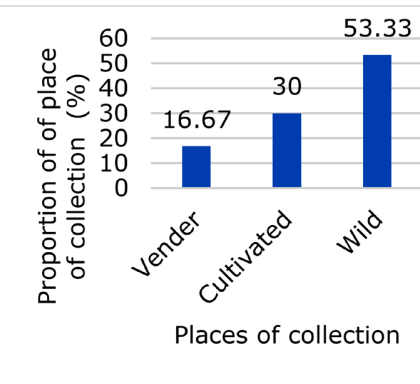

(c)

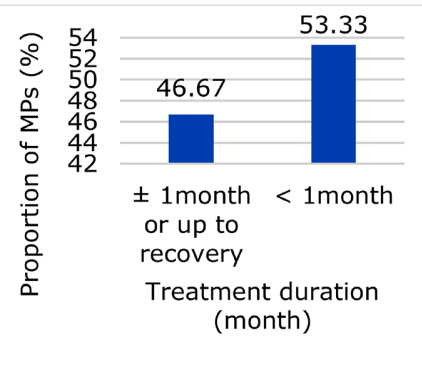

(f)

Figure 2. Indigenous MPs used in the management of MIs. Key: (a) Proportion of MPs used to treat MIs; (b) part used; (c) place of collection; (d) method of preparation; (e) routes of administration; (f) treatment duration; (g) method of diagnosis; (h) sources of knowledge.

The informant agreement ratio of plants used to treat anxiety ranged from 0.57 to 0.91. Cissus rubiginosa, D. adscendens (Sw), Passiflora edulis, and Akasia sieberiana were associated with highest level of IAR (>0.8) (Figure 3(b)). They represented the species with the highest level of consensus for their use as a remedy for anxiety. However, C. sumatrensis, E. coccinea (Sims) and O. basilicum represented the species with the highest IAR level (>0.15) (Figure 3(e)). They represented species with high level consensus for their use for depression.

\subsubsection{Informant Consensus Factor (ICF) and Species Therapeutic Potential (STP\%)}

Informant consensus factors were 0.87 for anxiety and 0.77 for depression. Two species with highest STP \% for anxiety identified and considered as having effective therapeutic potential included E. abyssinica and $C$. gynandra (Figure 3(c)). Two species with highest STP \% for depression identified and considered as having effective therapeutic potential included $C$. sumatrensis and $E$. coccinea (Sims) (Figure 3(f)). 


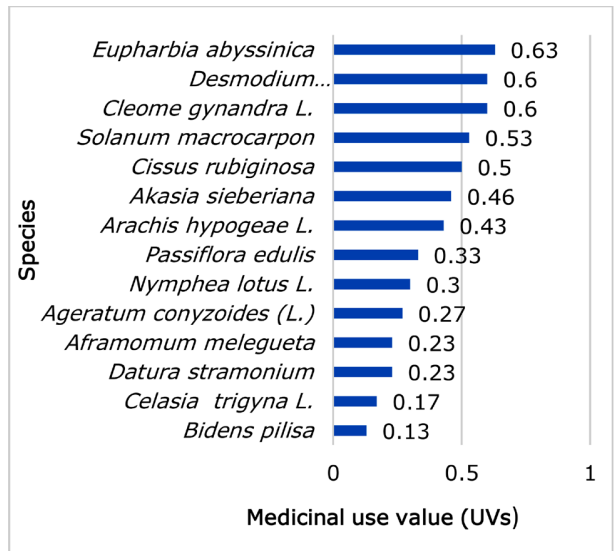

(a)

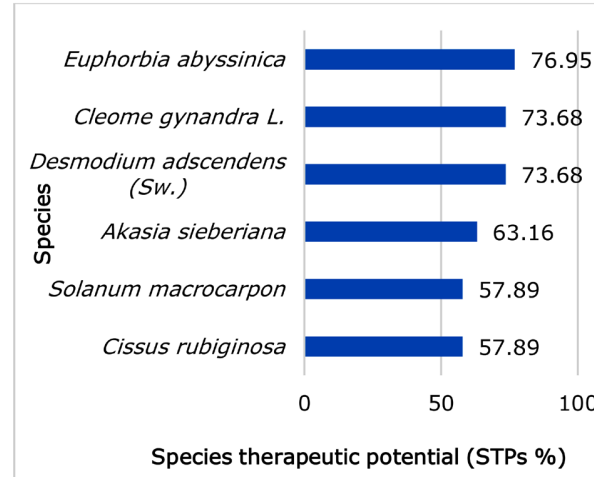

(c)

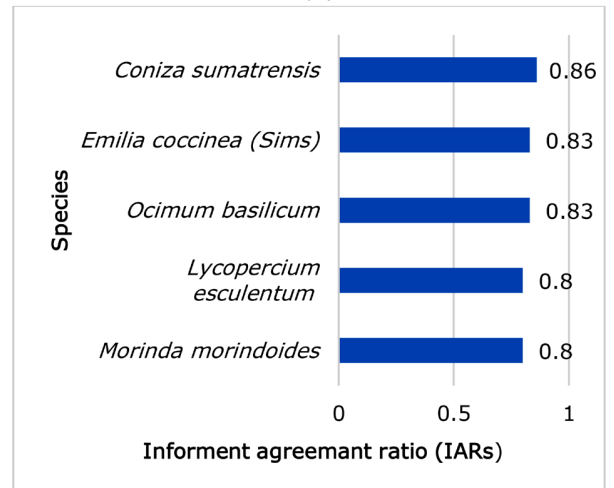

(e)

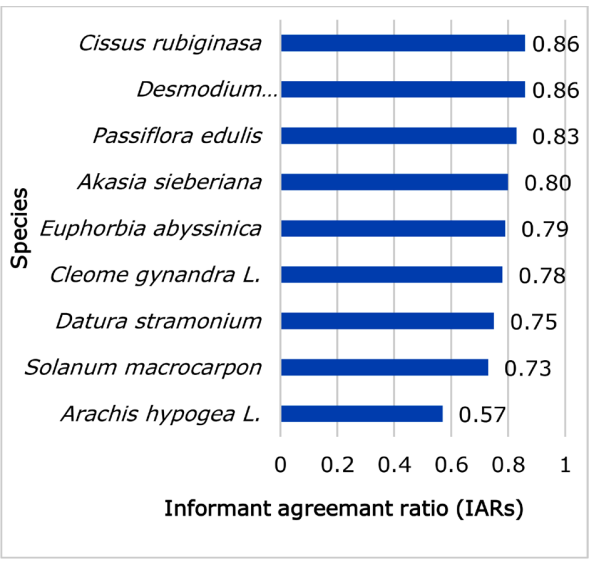

(b)

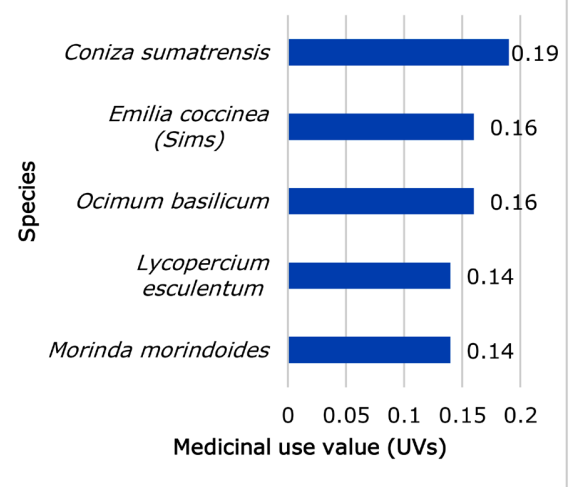

(d)

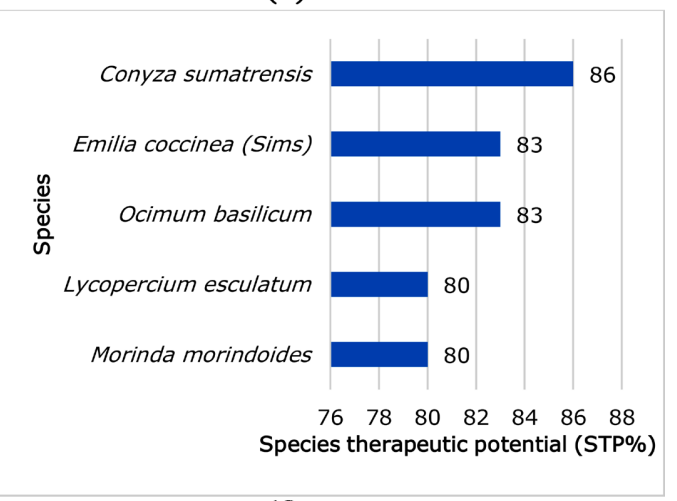

(f)

Figure 3. Ranking of priority plant species used in management of anxiety and depression. Key: (a) UV is use value of species used in management of anxiety; (b) IAR is informant agreement ratio of species used in management of anxiety; (c) STP is species therapeutic potential of plants used in management of anxiety; (d) UV is use value of species used in management of depression; (e) IAR is informant agreement ratio of species used in management of depression; (f) STP is species therapeutic potential of plants used in management of depression.

\subsection{Traditional Medicine Knowledge (TMK)}

Training was reported by more than half $(>50 \%)$ of THP as source of TMK. While inheritance from forefathers was reported by $23.26 \%$ of THP as source of TMK. Patient's story (60.46\%) and absence of MIs crisis (58.14\%) were most reported methods of diagnosis and recognition of healed patient respectively. 
There were no statistically significant differences $(p>0.05)$ between gender and Goma city TMK (based on number of reported medicinal species for depression, anxiety and psychosis). Also, there were no statistically significant differences ( $p>0.05$ ) between religions and Goma city TMK on MPs used for depression, but there were statistically significant differences between religions and Goma city TMK on MPs used for anxiety and psychosis. Positive Spearman correlation $(\mathrm{p}<0.05)$ were found between experience and age as well as experience and TMK on MPs used for depression, anxiety and psychosis $(\mathrm{p}<0.05)$. Also, positive Spearman correlation $(\mathrm{p}<0.05)$ was found between source of knowledge from forefather and TMK on MPs used for depression. Nevertheless, training and education level did not influence TMK $(p>0.05)$.

\section{Discussion}

\subsection{Taxonomic Diversity}

This study documented many plant species distributed in various families used as indigenous herbal medicines for management of MIs in Goma city. The families representing most species used in management of MIs included Asteraceae, Lamiacea and Solanaceae.

The frequent use of plant species of Asteraceae family in TM of the Goma city to treat MIs is probably due to their psychopharmacological activities. Indeed, according to Guenne et al. [38] plant species of Asteraceae family have phytochemical compounds that would have cholinergic, dopaminergic or serotoninergic system actions, which are major systems involved in the manifestation of neuropsychiatric disorders.

Plants species of Lamiaceae family are most used in TM of Goma city probably due to its pharmacological importance reported by Farzaneh et al. [39], especially their neurotropic activity as reported by Zvezdina et al. [40].

The explanation of the widespread use of species belonging to the Solanaceae is probably related to the fact that the family is source of tropane alkaloids including atropine, hyoscyamine and scopolamine, that are among the oldest drugs used in medicine due to their anticholinergic activity [41] [42]. Also, various pharmacological studies have demonstrated anxiolytic and antidepressant activities of species of Solanaceae family [43]. However, Solanaceae is comprised of several species that are toxic, and sometimes lethal to mammals, in particular to man [44].

\subsection{Common MPs Used in Management of MIs in Goma City}

Despite the fact that none of 30 MPs was associated with high FI $>50 \%$, high RSI was observed in the use of common species for MIs between THPs key informants from both Goma and Karisimbi communes.

The similarity of the use of common species for MIs is probably explained by the fact that training was reported as common source of knowledge by majority of THPs. Additionally, the high RSI may be linked to the fact that the two com- 
munes belong to the same phytogeographical environment and share more or less the same ecoclimatic and edaphic conditions and common realities [20].

\subsection{Indigenous MPs Use in Management of MIs}

Findings revealed that MPs used for anxiety were the most frequently cited than those used for psychosis and depression probably due to the fact that anxiety is one of commonest MIs in regions affected by war conflict such as NK as reported by WHO [4].

The majority of plant species used for psychosis are also used for anxiety. This is because the management of psychosis requires sedation for patient presenting agitation. It has been reported that some anxiolytic conventional drugs such as benzodiazepines decrease acute psychosis and have proven efficacy for agitation [45]. Also, it is established that atypical antipsychotic drugs possess multimodal mechanism of action including modulation of serotonin (5-HT), norepinephrine, histamine neurotransmission that underlies their benefs in mood and anxiety disorders [46]. However further studies are needed to elucidate the efficacy of these plants in anxiety and psychosis.

Leaves, decoction and oral ingestion were the most reported plant part used, method of preparation and mode of administration respectively. The preference medicinal use of leaves could probably be because they are easily and conveniently harvested [47], also they are the site par excellence of biosynthesis and storage of secondary metabolites, responsible for biological plant properties [48] [49]. Oral route is most preferred in TM of Goma Goma city probably due to the fact that it is noninvasive, high patient compliance, convenient to handle and does not require any specific conditions [50]. Decoction is used as method of preparation of most MPs for MIs in Goma city probably due to its easy preparation processes and probable ability to enhance the dissolution of some bioactive compounds compared with other methods of preparation such as maceration [51]. Wild MP collections were the mostly used in management of MIs due to the fact that overall DRC is rich in natural forests with various MPs [17] but also, probably due to the location of Goma city near Virunga national park reach in biodiversity. Overall, the duration of treatment of various MIs in TM was shorter ( $<1$ month) than that recommended by guidelines for pharmacotherapy of those ailments [52] [53]; due to claim that MPs might be most efficacious than conventional drugs [18]. However, experimental studies are needed for evidence of this claim.

\subsection{Relative Importance of a Given Plant}

Euphorbia abyssinica, D. adscendens, $C$. gynandra and $S$. macrocarpon were reported as the most important MPs for anxiety in traditional medicine of Goma city Pharmacopeia. Also, C. sumatrensis, E. coccinea and C. basilicum were reported in the study as the most important MPs for depression in TM of Goma city Pharmacopeia. However, C. rubiginosa, D. adscendens, P. edulis, and A. Sie- 
beriana represented the species with the highest level of consensus for their use by THP as remedies for anxiety.

Indeed, the present study analysis demonstrated that $E$. abyssinica had highest STP\%. Latex from E. abyssinica has been reported to have antibacterial and antifungal activities [73]. The medicinal effects of the plant are mainly confined to its latex and roots [74]. However, it is rather classified as a poisonous plant by the Food and Drug Administration of the United States of America [75] and no much is known on its use as drug against MIs. Pharmacological and toxicological studies are needed to justify its use against MIs in TM of Goma city.

Desmodium adscendens is a plant which has been scientifically proven for its diverse positive CNS pharmacological activities. Its ethanolic extract has been proven to induce hypothermia, possessed analgesic effect and reduced the tonic phase of convulsion, and eventually mortality in PTZ-treated mice [76]. According to the authors, the plant species extract might act through the opioidergic, adrenergic systems, adenosine triphosphate (ATP)-sensitive K+ channels, and the serotoninergic pathways to ameliorate pain in murine models that probably explain its use as MIs therapy in TM of Goma city.

Several research reveal that $C$. gynandra possesses a huge range pharmacological applications, including anti-inflammatory, free radical scavenging, as well as its analgesic activities [77] [78]. Also, scientific perusal reveals that different parts of the plant are of immense medicinal importance which may prove its traditional use in DRC. Among species of Cleome genera, studies conducted by Sana et al. [79] and Tabariyeng [80] concluded that Cleome brachycarpa possesses anxiolytic and CNS depressant effect after acute dosing. Despite its high SPT\% revealed by this study, to date, there is not much research investigation for pharmacological importance of $C$. gynadra for MIs. Thus, psychopharmacological studies are suggested to explain its use in management of MI in Goma city.

Study conducted by Eletta et al. [81] and Ozioko and al. [82] showed that the aqueous extract of $S$. macrocarpon leaf has dependent significant antioxidant property on the experimental rats. Also, the study conducted by Oluwagunwa et al. [83] revealed the antihypertensive activity of the plant species in rats due to activities of renin and angiotensin converting enzyme to varying extents. Psychopharmacological study of the plant species was also suggested to elucidate its use in TM of Goma city as therapeutic agent against MIs.

Conyza sumatrensis has demonstrated antimalarial activity through in-vivo evaluation in Plasmodium berghei infected mice through the study that was conducted by Pone and Anirba [84]. The study conducted by Olapeju et al. [85] showed antimicrobial activity of the plant. However, no literature was found regarding its antidepressant activity.

Simplice et al. [86] reported neuroprotective and memory improvement effects of $E$. coccinea in animal models. Thus, the folkloric usage of this plant for the treatment of MIs is probably justified by those previous studies.

The indigenous use of $O$. basilicum in management of MIs in Goma city is 
probably supported by varieties of experimental models that has demostreted the CNS depressant and anticonvulsant activity of the essential oil of the plant species obtained from leaves. According to Khair-ul-Bariyah et al. [87], the CNS depressant activity could be mediated by central GABAergic receptors.

Regarding plant species with highest level of consensus for anxiety, C. rubiginosa root extract possesses stimulant CNS function suggested by decreasing exploratory actions, its methanol root extract comprises saponins that exhibit powerful sedative action and also suppress spontaneous motor action in mice [88]. The study conducted by Xirui et al. [89], suggested that $P$. edulis possess antidepressant activity related exclusively to regulate serotonergic and dopaminergic transmission such as $5-\mathrm{HT}$, catecholamine and $\mathrm{D}_{2}$ receptor. Akasia sieberiana has been reported to possess anti-inflammatory and anti-nociceptive pharmacological activities. According to Archer et al. [90], its anti-nociceptive effect may relatively be attributed to interactions with muscarinic cholinergic, adenosinergic and opioidergic system. The study revealed that the plant species possesses anxiolytic and sedative activities.

\section{Medicinal knowledge}

There were no statistically significant differences between gender and Goma city TMK. This finding is contradictory to previous studies showing that, in general, women know more than men about MPs [91]; some authors suggest that this is because men are more exposed to losing ethnobotanical plant knowledge than women [92]. Women's work activities in home gardens and as primary family health caregivers might explain this literature finding [93] [94]. The explanation of the finding from Goma city is probably residing in fact that more than half (55.56\%) of THPs, have their source of TMK from training that might be the same for both sexes.

Statistically significant differences between religions and of Goma city TMK Goma city for anxiety and psychosis may be explained by the fact that majority indigenous African communities believe that most cases of MIs have supernatural causes such as sorcery, curses and punishment from the deity [95]. According to IRBC [9] many Congolese believe in religion for treatment of MI.

Positive Spearman correlations were found between experience and age as well as experience and TMK for depression, anxiety and psychosis. Elders THPs tended to gain experience and to know more about MPs than younger THPs. Several other authors found the same tendency in their studies about MP knowledge in different parts of the world [96] [97] [98]. Reasons are that with progressive age, people have more time to accumulate knowledge and, therefore, show greater MP knowledge than the younger generation [99]. Other authors associate the lesser knowledge in the younger population in ongoing socio-economic and cultural changes [100].

Also, positive Spearman correlation was found between source of knowledge from forefather and TMK. According to some authors, TMK is mostly tacit in nature and is passed on from one person to another [101]. Elders are considered 
to be the legitimate custodians of this knowledge which was handed down to them by their ancestors, and they are in turn expected to pass it on to others [102]. This probably explains the fact that TMK of Goma city is most influenced by forefather's knowledge.

Finding of the study revealed that training and education level did not influence TMK for depression in Goma city. The same result has been linked to that rapid socio-cultural changes due to globalization processes. Increased accessibility to health centers and improved transportation infrastructure result in a loss of ethnobotanical knowledge [103]. Additional explanation regarding TMK of Goma city is probably the lack of integration of TM in general curriculum of education of DRC.

\section{Conclusion}

Results prove that interesting MPs species are used by TM of Goma city against MIs. Thirty MPs species classified in 29 genera and 19 families are used in indigenous medicine of Goma city to manage MIs. A high similarity was observed in the use of common species for MIs between THPs key informants from both Goma and Karisimbi communes. Among MPs used in Goma city, the two priority plant species for anxiety include $E$. abyssinica and $C$. gynandra L. Also, the two priority plant species for depression include $C$. sumatrensis and E. coccinea. The priority MPs could be further studied for pharmacological applications and safety.

\section{Acknowledgements}

I am grateful to Dr. Esther Katuura of School of Biological Sciences, College of Natural Sciences of Makerere University, Dr. Godfrey Bbosa and Dr. John Odda of the Department of Pharmacology \& Therapeutics Makerere University College of Health Science, Professor Zacharie Tsongo Kibendelwa of Faculty of Human Medicine, University of in Goma city/DRC, all Doctoral and Ethical committee members of Makerere University, Ministry of Health in Goma city/DRC. I am also very grateful to Traditional Healers Team Leaders of Goma city/DRC.

\section{Conflicts of Interest}

The authors declare no conflicts of interest regarding the publication of this paper.

\section{References}

[1] American Psychiatric Association (2000) Diagnostic and Statistical Manual-Text Revision (DSM-IV-TRim, 2000).

[2] Charlson, F., van Ommeren, M., Flaxman, A., Cornett, J., Whiteford, H. and Saxena, S. (2019) New WHO Prevalence Estimates of Mental Disorders in Conflict Settings: A Systematic Review and Meta-Analysis. The Lancet, 394, 240-240. https://doi.org/10.1016/S0140-6736(19)30934-1

[3] Si, S., Moss, J., Sullivam, T., Nowton, S. and Stoks, N. (2014) Effectiveness of Gener- 
al Practice-Based Health Check: A Systemic Review and Meta Analysis. Practice: The Journal of the Royal College of General Practitioner, 4, 47-53. https://doi.org/10.3399/bjgp14X676456

[4] Depression WH (2017) Depression and Other Common Mental Disorders: Global Health Estimates. Geneva.

[5] Mogga, J.L. (2019) The Mental Health Treatment Gap in South Sudan. South Sudan Medical Journal, 12, 28-29.

[6] On'okoko, M.O., Jenkins, R., Miezi, S.M.M., Andjafono, D.O.L.E. and Mushidi, I.M. (2010) Mental Health in the Democratic Republic of Congo: A Post-Crisis Country Challenge. International Psychiatry, 7, 41-43. https://doi.org/10.1192/S1749367600005737

[7] Kangoy, A.K., Muloye, G.M., Avevor, P.M. and Shixue, L. (2016) Mental Health Consequences of Being Raped in the Eastern Region of the Democratic Republic of Congo. Donnish Journal of Medicine and Medical Sciences, 3, 6-10.

[8] Stephanie, E. (2016) Barriers to Mental Health Treatment with the Congolese Population.

[9] Immigration and Refugee Board of Canada (2012) République Démocratique du Congo (RDC), information sur le traitement réservé aux personnes ayant des troubles de santé mentale. Protection et services offerts par l'État, COD104104. Commission d'immigration et de status des refugiés, UNHCR, 14 June. http://www.irbcisr.gc.ca:8080/RIR_RDI/RIRRDI.aspx?id=454030\&l=f

[10] Kosi, R.S. (2008) Au moins 15 millions de personnes atteintes des troubles mentaux en RDC. Le Potentiel, Kinshasa. https://www.refworld.org/docid/50eac4c92.html

[11] Verelst, A., De Schryver, M., Broekaert, E. and Derluyn, I. (2014) Mental Health of Victims of Sexual Violence in Eastern Congo: Associations with Daily Stressors, Stigma, and Labeling. BMC Women's Health, 14, 1-12. https://doi.org/10.1186/1472-6874-14-106

[12] Mels, C., Derluyn, I., Broekaert, E. and Rosseel, Y. (2009) Screening for Traumatic Exposure and Posttraumatic Stress Symptoms in Adolescents in the War-Affected Eastern Democratic Republic of Congo. Archives of Pediatrics \& Adolescent Medicine, 163, 525-530. https://doi.org/10.1001/archpediatrics.2009.56

[13] Dossa, N.I., Hatem, M., Zunzunegui, M.V. and Fraser, W. (2014) Social Consequences of Conflict-Related Rape: The Case of Survivors in the Eastern Democratic Republic of Congo. Peace and Conflict: Journal of Peace Psychology, 20, 241-255. https://doi.org/10.1037/pac0000044

[14] Laudati, A.A. (2014) Negotiations and Networks in the Cannabis Trade in Eastern Democratic Republic of Congo. In: Drugs in Africa, Palgrave Macmillan, New York, 161-181. https://doi.org/10.1057/9781137321916_9

[15] Meyer, P.K. (2018) Republique Demacratique du Congo: Developpement. Organisation Suisse d'Aide aux Refugies. Ritchie, H. Global Mental Health: Five Key Insights Which Emerge from the Data. Our World in Data, Online, 16 May.

[16] World PsycShiatry (2007) The Concept of Mental Disorder. African Perspective, 6, 166-167.

[17] Vancutsem, C., Pekel, J.F., Kibambe Lubamba, J.P., Blaes, X., de Wasseige, C. and Defourny, P. (2006) Carte de l'occupation du sol de la République Démocratique du Congo. UCL-Geomatics.

[18] Edgerton, R.B. (1980) Traditional Treatment for Mental Illness in Africa: A Review. Culture, Medicine and Psychiatry, 4, 167-189. https://doi.org/10.1007/BF00051433 
[19] Lukongo, O.E. (2018) Trans-Border Trade, Minerals, and Civil War Impacts on Land Use and Land Cover Change in GOMA, Eastern Congo: An Integrated Geospatial Technologies and Political Economy Approach. International Journal of Advanced Robotics and Automation, 3, 1-12. https://doi.org/10.15226/2473-3032/3/1/00129

[20] INS-Nord-Kivu (2016) Goma et ses avenues. Division Provincial du Plan, Goma.

[21] T. g. C. t. (2013) Climate: Goma-Climate Graph. Climate-Data.org.

[22] Malembaka, E.B., Altare, C., Bigirinama, R.N., Bisimwa, G., Banywesize, R., Tabbal, N. and Boerma, T. (2021) The Use of Health Facility Data to Assess the Effects of Armed Conflicts on Maternal and Child Health: Experience from the Kivu, DR Congo. BMC Health Services Research, 21, 1195. https://doi.org/10.1186/s12913-021-06143-7

[23] A. F. P. Agency (2021) @AFPAfrica Map of DR Congo Locating Goma in Notth Kivu, Where Italy's Ambassador to the Country Was Killed after Gunmen Attacked a UN Convoy, AFP Graphics.

[24] Kumar, R. (2011) Research Methodology: A Step-by-Step Guide for Beginners. EC1Y 1SP, SAGE Publications Ltd., London. http://www.sagepublication.com

[25] Kumar, R.V. (2014) Respondent Selection Methods in Household Surveys. International Management Institute, New Delhi, 1-9. http://www.sagepublication.com

[26] Mashako, M. (2002) Arrêté Ministériel n 1250/CAB MIN/S/CJ/KIZ/32/2002 du 25/ $10 / 2002$ portant organisation de l'exercice de la médecine traditionnelle. Ministère congolais de la santé, RD. Congo. Kinshasa RDC, 8 p.

[27] Pretorius, E. (1999) Traditional Healers. South African Health Review, 249, 256.

[28] Boddy, C. (2016) Sample Size for Qualitative Research. Qualitative Market Research, 19, 426-432. https://doi.org/10.1108/QMR-06-2016-0053

[29] Phillips, O.L. and Gentry, A.H. (1993) The Useful Plants of Tambopata, Peru: II. Additional Hypotheses Testing in Quantitative Ethnobotany. Economic Botany, 47, 33-43. https://doi.org/10.1007/BF02862204

[30] Evert, T., Vandebroek, I., Sabino, S. and Van Damme, P. (2009) Cultural Significance of Medicinal Plant Families and Species among Quechua Farmers in Apillapampa, Bolivia. Journal of Ethnopharmacology, 122, 60-67. https://doi.org/10.1016/j.jep.2008.11.021

[31] Trotter, R.T. and Logan, M.H. (1986) Informant Consensus: A New Approach for Identifying Potentially Effective Medicinal Plants. In: Etkin, N.L., Eds., Plants in Indigenous Medicine and Diet, Behavioural Approaches, Redgrave Publishing Company, New York, 91-112. https://doi.org/10.4324/9781315060385-6

[32] Latham, P. and Konda Ku Mbuta, A. (2014) Useful Plants of Bas-Congo Province, Democratic Republic of Congo. Salvation Army, 2, 292.

[33] Bakwaye, F.N., Termote, C., Kembelo, A.K. and Van Damme, P. (2015) Identification et importance locale des plantes médicinales utilisées dans la région de MbanzaNgungu, République démocratique du Congo. Bois \& forêts des tropiques, 316, 63-77. https://doi.org/10.19182/bft2013.316.a20531

[34] Heinrich, M. (2000) Ethnobotany and Its Role in Drug Development. Phytotherapy Research: PTR, 14, 479-488. https://doi.org/10.1002/1099-1573(200011)14:7<479::AID-PTR958>3.0.CO;2-2

[35] Nachar, N. (2008) The Mann-Whitney U: A Test for Assessing Whether Two Independent Samples Come from the Same Distribution. Tutorials in Quantitative Me- 
thods for Psychology, 4, 13-20. https://doi.org/10.20982/tqmp.04.1.p013

[36] Lesić, K.T., Brščić, K. and Ružić, M.D. (2017) The Importance of Understanding Event Experience. Tourism in South East Europe, 4, 605-618.

https://doi.org/10.20867/tosee.04.26

[37] Rahman, I.U., Afzal, A., Iqbal, Z., Hart, R., Ef, A.A., Hashem, A., Alsayed, M.F., Ijaz, F., Ali, N., Shah, M., Bussmann, R.W. and Calixto, E.S. (2019) A New Ethnobiological Similarity Index for the Evaluation of Novel Use Reports. Applied Ecology and Environmental Research, 17, 2765-2777. https://doi.org/10.15666/aeer/1702_27652777

[38] Guenne, S., Balmus, I.M., Hilou, A., Ouattara, N., Kiendrebéogo, M., Ciobica, A. and Timofte, D. (2016) The Relevance of Asteraceae Family Plants in Most of the Neuropsychiatric Disorders Treatment. International Journal of Phytopharmacy, $\mathbf{8}$, 176-182.

[39] Farzaneh, N., Mahmoud, M., Saeed, M. and Abdolbaset, G. (2005) Labiatae Family in folk Medicine in Iran. Iranian Journal of Pharmaceutical Research, 2, 63-79.

[40] Zvezdina, E.V., Dayronas, J.V., Bochkareva, I.I., Zilfikarov, I.N., Babaeva, E.Yu., Ferubko, E.V., Guseynova, Z.A., Serebryanaya, F.K., Kaibova, S.R. and Ibragimov, T.A. (2020) Members of the Family Lamiaceae Lindl. as Sources of Medicinal Plant Raw Materials to Obtain Neurotropic Drugs. Pharmacy \& Pharmacology, 8, 4-28. https://doi.org/10.19163/2307-9266-2020-8-1-4-28

[41] Oksman-Caldentey, K.M. (2007) Tropane and Nicotine Alkaloid BiosynthesisNovel Approaches towards Biotechnological Production of Plant-Derived Pharmaceuticals. Current Pharmaceutical Biotechnology, 8, 203-210.

https://doi.org/10.2174/138920107781387401

[42] Hashimoto, T., Yun, D.J. and Yamada, Y. (1993) Production of Tropane Alkaloids in Genetically Engineered Root Cultures. Phytochemistry, 32, 713-718. https://doi.org/10.1016/S0031-9422(00)95159-8

[43] Bhattacharya, S.K., Bhattacharya, A., Sairam, K. and Ghosal, S. (2000) AnxiolyticAntidepressant Activity of Withania somnifera Glycowithanolides: An Experimental Study. Phytomedicine, 7, 463-469. https://doi.org/10.1016/S0944-7113(00)80030-6

[44] Pomilio, A.B., Falzoni, E.M. and Vitale, A.A. (2008) Toxic Chemical Compounds of the Solanaceae. Natural Product Communications, 3, 593-628. https://doi.org/10.1177/1934578X0800300420

[45] Hannah, E.B., Joseph, S. and Oliver, F. (2012) How to Stabilize an Acutely. Current Psychiatry, 11, 10-16.

[46] Grinchii, D. and Dremencov, E. (2020) Mechanism of Action of Atypical Antipsychotic Drugs in Mood Disorders. International Journal of Molecular Sciences, 21, 9532. https://doi.org/10.3390/ijms21249532

[47] Bhattarai, S. (2006) Ethnomedicinal Plants Used by the People of Manang District, Central Nepal. Journal of Ethnobiology and Ethnomedicine, 2, 41.

https://doi.org/10.1186/1746-4269-2-41

[48] Kumar, P. and Lalramnghinglova, H. (2011) India with Special Reference to an Indo-Burma Hotspot Region. Ethnobotany Research and Applications, 9, 379-342. https://doi.org/10.17348/era.9.0.379-420

[49] Srithi, K., Balslev, H., Wangpakapattanawong, P., Srisanga, P. and Trisonthi, C. (2009) Medicinal Plant Knowledge and Its Erosion among the Mien (Yao) in Northern Thailand. Journal of Ethnopharmacology, 123, 335-342. 
https://doi.org/10.1016/j.jep.2009.02.035

[50] Deviprasad, S. and Rambabu, D. (2021) Oral Drug Delivery of Nanomedicine. In: Theory and Applications of Nonparenteral Nanomedicines, Academic Press, Cambridge, 181-207. https://doi.org/10.1016/B978-0-12-820466-5.00009-0

[51] Zhang, Q.W., Lin, L.G. and Ye, W.C. (2018) Techniques for Extraction and Isolation of Natural Products: A Comprehensive Review. Chinese Medicine, 13, 1-26. https://doi.org/10.1186/s13020-018-0177-x

[52] Remington, G., Addington, D., Honer, W., Ismail, Z., Raedler, T. and Teehan, M. (2017) Guidelines for the Pharmacotherapy of Schizophrenia in Adults. The Canadian Journal of Psychiatry, 62, 604-616. https://doi.org/10.1177/0706743717720448

[53] Mary, A.K. (2009) Applied Therapeutics: The Chemical Use of Drugs. Lippincott Williams \& Wilkins, Baltimore.

[54] Levin, S. (2013) Encyclopedia of Biodiversity. Elsevier Inc., Amsterdam.

[55] Kaur, R. and Kaur, S. (2015) Anxiolytic Potential of Methanol Extract from Ageratum Conyzoides Linn Leaves. Pharmacognosy Journal, 7, 236-241.

https://doi.org/10.5530/pj.2015.4.5

[56] Seol, G.H., Shim, H.S., Kim, P.J., Moon, H.K., Lee, K.H., Shim, I., Suh, S.H. and Min, S.S. (2010) Antidepressant-Like Effect of Salvia sclarea Is Explained by Modulation of Dopamine Activities in Rats. Journal of Ethnopharmacology, 130, 187-190. https://doi.org/10.1016/j.jep.2010.04.035

[57] Ali, S.S., Abd El Wahab, M.G., Ayuob, N.N. and Suliaman, M. (2017) The Antidepressant-Like Effect of Ocimum basilicum in an Animal Model of Depression. Biotechnic \& Histochemistry, 92, 390-401. https://doi.org/10.1080/10520295.2017.1323276

[58] Jedi-Behnia, B., AbbasiMaleki, S. and Mousavi, E. (2017) The Antidepressant-Like Effect of Mentha spicata Essential Oil in Animal Models of Depression in Male Mice. Journal of Fasa University of Medical Sciences, 7, 141-149.

[59] Machado, D.G., Neis, V.B., Balen, G.O., Colla, A., Cunha, M.P., Dalmarco, J.B., Pizzolatti, M.G., Prediger, R.D. and Rodrigues, A.L. (2012) Antidepressant-Like Effect of Ursolic Acid Isolated from Rosmarinus officinalis L. in Mice: Evidence for the Involvement of the Dopaminergic System. Pharmacology Biochemistry and Behavior, 103, 204-211. https://doi.org/10.1016/j.pbb.2012.08.016

[60] Tiwari, A.T., Rathi, J.R., Dwivedi, S.K., Sanno, S. and Tripathi, S.T. (2018) Evaluation of Anti Anxiety Activity of Datura Seeds in Mice. International Journal of Indigenous Herbs and Drugs, 3, 23-24.

[61] Jawad, M., Khan, H., Pervaiz, S., Bawazeer, S.S., Abu-Izneid, T., Saeed, M. and Kamal, M.A. (2017) Pharmacological Validation of the Anxiolytic, Muscle Relaxant and Sedative Like Activities of Capsicum annuum in Animal Model. Bangladesh Journal of Pharmacology, 12, 439-447. https://doi.org/10.3329/bjp.v12i4.33182

[62] Lorigooini, Z., Dehsahraei, K.S., Bijad, E., Dehkordi, S.H. and Amini-Khoei, H. (2020) Trigonelline through the Attenuation of Oxidative Stress Exerts Antidepressant- and Anxiolytic-Like Effects in a Mouse Model of Maternal Separation Stress. Pharmacology, 105, 289-299. https://doi.org/10.1159/000503728

[63] Revathy, C. (2016) Neuropsychopharmacological Evaluation of Kalyanakam Kashayam (An Ayurvedic Formulation) in Swiss Albino Mice. Doctoral Dissertation, KMCH College of Pharmacy, Coimbatore.

[64] Zu, X., Zhang, Z., Xiong, G., Liao, T., Qiao, Y., Li, Y., Geng, S. and Li, X. (2013) Sedative Effects of Arachis hypogaea L. Stem and Leaf Extracts on Sleep Deprived 
Rats. Experimental and Therapeutic Medicine, 6, 601-605. https://doi.org/10.3892/etm.2013.1182

[65] Islam, S., Shajib, M.S., Datta, B.K. and Rashid, M.A. (2018) Neuropharmacological Activities of Methanol Extract of Albizia lebbeck (L.) Benth. Bangladesh Pharmaceutical Journal, 21, 80-86. https://doi.org/10.3329/bpj.v21i2.37917

[66] Kinda, P.T., Zerbo, P., Guenné, S., Compaoré, M., Ciobica, A. and Kiendrebeogo, M. (2017) Medicinal Plants Used for Neuropsychiatric Disorders Treatment in the Hauts Bassins Region of Burkina Faso. Medicines, 4, 32. https://doi.org/10.3390/medicines4020032

[67] Umukoro, S. and Ashorobi, R.B. (2005) Anti-Stress Potential of Aqueous Seed Extract of Aframomum melegueta. African Journal of Biomedical Research, 8, 119-121. https://doi.org/10.4314/ajbr.v8i2.35771

[68] Fajemiroye, J.O., Adam, K., Zjawiony Jordan, K., Alves, C.E. and Aderoju, A.A. (2018) Evaluation of Anxiolytic and Antidepressant-Like Activity of Aqueous Leaf Extract of Nymphaea lotus Linn. in Mice. Iranian Journal of Pharmaceutical Research: IJPR, 17, 613.

[69] Begum, A., Biswas, P. and Shahed-Al-Mahmud, M. (2020) Methanol Extract of Spathodea campanulata P.(Beauv.) Leaves Demonstrate Sedative and Anxiolytic Like Actions on Swiss Albino Mice. Clinical Phytoscience, 6, 1-2. https://doi.org/10.1186/s40816-020-00182-Z

[70] Amin, K.R., Uddin, M.G., Rashid, M.M. and Sharmin, T. (2018) New Insight in Neuropharmacological Activities of Dioscorea alata. Discovery Phytomedicine, 5, 1-6. https://doi.org/10.15562/phytomedicine.2018.52

[71] Deng, J., Zhou, Y., Bai, M., Li, H., Li, L. and Deng, J. (2010) Anxiolytic and Sedative Activities of Passiflora edulis f. Flavicarpa. Journal of Ethnopharmacology, 128, 148153. https://doi.org/10.1016/j.jep.2009.12.043

[72] Abubakar, A.R. and Haque, M. (2019) Medicinal Plants with Reported Anxiolytic and Sedative Activities in Nigeria: A Systematic Review. Istanbul Journal of Pharmacy, 49, 92-104. https://doi.org/10.26650/IstanbulJPharm.2019.18008

[73] El-Fiky, F., Asres, K., Gibbons, S., Hammoda, H., Badr, J. and Umer, S. (2008) Phytochemical and Antimicrobial Investigation of Latex from Euphorbia abyssinica Gmel. Natural Product Communications, 3, 1505-1508. https://doi.org/10.1177/1934578X0800300922

[74] Muluye, A.B., Desta, A.G., Abate, S.K. and Dano, G.T. (2019) Anti-Malarial Activity of the Root Extract of Eupharbia abyssinica (Euphorbiaceae) against Plasmodium berghei Infection in Mice. Malaria Journal, 12, 261. https://doi.org/10.1186/s12936-019-2887-7

[75] USA Food and Drug Administration (2018) FDA Poisonous Plant Database. Food and Drug Administration of United States of America.

https://www.accessdata.fda.gov/scripts/plantox/detail.cfm?id=23140

[76] Bonsu, A.S. (2017) Studies on the Analgesic Effect and Toxicity Profile of Ethanolic Extractive of Desmodium adscendens in Rodents, Legon. University of Ghana School of Pharmacy, Accra.

[77] Adhikari, P.P. and Paul, S.B. (2018) Medicinally Important Plant Cleome gyndra: A Phytochemical and Pharmacological Explanation. Asian Journal of Pharmaceutical and Clinical Research, 11, 21-29. https://doi.org/10.22159/ajpcr.2018.v11i1.22037

[78] Mishra, S.S., Moharana, S.K. and Dash, M.R. (2011) Review on Cleome gynandra. International Journal of Research in Pharmacy and Chemistry, 1, 681-689. 
[79] Sarfaraz, S., Najam, R.A., Azhar, I., Riaz, B. and Anser, H.U. (2014) Anxiolytic and CNS Depressant Effects of Ethanolic Extract of Cleome Brachycarpa Revealed after Neuropharmacological Screening. World Journal of Pharmaceutical Sciences, 2, 605-610.

[80] Justice, T.N. (2019) Anti-Convulsant and Sedative Effects of the Hydro-Ethanolic Whole Plant Extraction of Cleome rutidosperma (DC.) (Cleomeceae) in Mice. University of Ghana, Accra.

[81] Eletta, O., Orimolade, B., Oluwaninyi, O. and Oo, D. (2017) Evaluation of Proximate and Antioxidant Activities of Ethiopian Eggplant (Solanum aethiopicum L) and Gboma Eggplant (Solanum macrocarpon L). Journal of Applied Sciences and Environmental Management, 21, 967-972. https://doi.org/10.4314/jasem.v21i5.25

[82] Mary, O.O., Sebastine, O.U., Ejuiwa, M.C., Ikemefuna, O.I. and Dominic, E. (2020) Anxiolytic and Curative Effect of Solanum macrocarpon Leaves Extract on Acetaminophen Induced Brain Injury in Adult Wistar Rats. Journal of Pharmacognosy and Phytochemistry, 9, 205-212.

[83] Oluwagunwa, O.A., Alashi, A.M. and Aluko, R.E. (2019) Solanum macrocarpon Leaf Extracts Reduced Blood Pressure and Heart Rate after Oral Administration to Spontaneously Hypertensive Rats. Current Topics in Nutraceutical Research, 17, 282-290. https://doi.org/10.37290/ctnr2641-452X.17:282-290

[84] Boniface, P.K. and Pal, A. (2012) Substantiation of the Ethnopharmacological Use of Conyza sumatrensis (Retz.) E.H. Walker in the Treatment of Malaria through in Vivo Evaluation in Plasmodium berghei Infected Mice. Elsevier Ireland Ltd., Amsterdam.

[85] Aiyelaagbe, O.O., Oguntoye, S.O., Hamid, A.A., Ogundare, A.M., Ojo, D.B., Ajao, A. and Owolabi, N.O. (2016) GC-MS Analysis, Antimicrobial and Antioxidant Activities of Extracts of the Aerial Parts of Conyza sumatrensis. Journal of Applied Sciences and Environmental Management, 20, 103-110.

https://doi.org/10.4314/jasem.v20i1.13

[86] Simplice, F.H., Abdou, B.A., Abaissou, N., Hervé, H., Lucy, M.F., Annabel, M.N., Nyenti, S., Neh, P. and Acha, A.E. (2014) Neuroprotective and Memory Improvement Effects of a Standardized Extract of Emilia coccinea (SIMS) G. on Animal Models of Anxiety and Depression. Journal of Pharmacognosy and Phytochemistry, 3, 146-154.

[87] Bariyah, S.K., Ahmed, D. and Ikram, M. (2012) Ocimum basilicum: A Review on Phytochemical and Pharmacological Studies. Pakistan Journal of Chemistry, 2, 78-85. https://doi.org/10.15228/2012.v02.i02.p05

[88] Sundaran, J. (2020) A Short Review on Pharmacological Activity of Cissus quadrangularis. Biomedical Informatics, 16, 579-585.

https://doi.org/10.6026/97320630016579

[89] He, X., Luan, F., Yang, Y., Wang, Z., Zhao, Z., Fang, J., Wang, M., Zuo, M. and Li, Y. (2020) Passiflora edulis. An Insight into Current Researches on Phytochemistry and Pharmacology. Frontiers in Pharmacology, 11, 617. https://doi.org/10.3389/fphar.2020.00617

[90] Archer, M.A., Agyei, A., Mintah, S., Adjei, P., Kumadoh, D. and Asiedu-Larbi, J. (2019) Medicinal Uses of Cassia sieberiana; a Review. International Journal of Sciences. Basic and Applied Research, 48, 161-180.

[91] Weckmüller, H., Barriocanal, C., Maneja, R. and Boada, M. (2019) Factors Affecting Traditional Medicinal Plant Knowledge of the Waorani, Ecuador. Sustainability, 11, 2-12. https://doi.org/10.3390/su11164460 
[92] Reyes-García, V., Guèze, M., Luz, A., Paneque-Gálvez, J., Macía, M., Orta-Martínez, M., Pino, J. and Rubio-Campillo, X. (2013) Evidence of Traditional Knowledge Loss among a Contemporary Indigenous Society. Evolution and Human Behavior, 34, 249-257. https://doi.org/10.1016/j.evolhumbehav.2013.03.002

[93] Camou-Guerrero, A., Reyes-García, V., Martínez-Ramos, M. and Casas, A. (2008) Knowledge and Use Value of Plant Species in a Rarámuri Community: A Gender Perspective for Conservation. Human Ecology, 36, 259-272. https://doi.org/10.1007/s10745-007-9152-3

[94] Coe, F. and Anderson, G. (1996) Screening of Medicinal Plants Used by the Garifuna of Eastern Nicaragua for Bioactive Compounds. Journal of Ethnopharmacology, 53, 29-50. https://doi.org/10.1016/0378-8741(96)01424-9

[95] Abdullahi, A.A. (2011) Trends and Challenges of Traditional Medicine in Africa. African Journal of Traditional, Complementary and Alternative Medicines, 8, 115 123. https://doi.org/10.4314/ajtcam.v8i5S.5

[96] Matavele, J. and Habib, M. (2000) Ethnobotany in Cabo Delgado, Mozambique: Use of Medicinal Plants. Environment, Development and Sustainability, 2, 227-234. https://doi.org/10.1023/A:1011414124429

[97] Begossi, A., Hanazaki, N. and Tamashiro, J. (2002) Medicinal Plants in the Atlantic Forest (Brazil): Knowledge, Use, and Conservation. Human Ecology, 30, 281-299. https://doi.org/10.1023/A:1016564217719

[98] Merétika, A., Peroni, N. and Hanazaki, N. (2010) Local Knowledge of Medicinal Plants in Three Artisanal Fishing Communities (Itapoá, Southern Brazil), According to Gender, Age, and Urbanization. Acta Botanica Brasilica, 24, 386-394. https://doi.org/10.1590/S0102-33062010000200009

[99] Voeks, R. and Leony, A. (2004) Forgetting the Forest: Assessing Medicinal Plant Erosion in Eastern Brazil. Economic Botany, 58, S294-S306. https://doi.org/10.1663/0013-0001(2004)58[S294:FTFAMP]2.0.CO;2

[100] Figueiredo, G., Leitao-Filho, H. and Begossi, A. (1997) Ethnobotany of Atlantic Forest Coastal Communities: II. Diversity of Plant Uses at Sepetiba Bay (SE Brazil). Human Ecology, 25, 353-360. https://doi.org/10.1023/A:1021934408466

[101] Osemene, K.P., Elujoba, A.A. and Ilori, M.O. (2011) An Overview of Herbal Medicine. Research and Development in Nigeria. Research Journal of Medical Sciences, 5, 8. https://doi.org/10.3923/rjmsci.2011.228.232

[102] Owuor, J. (2007) Integrating African Indigenous Knowledge in Kenya's Formal Education System: The Potential for Sustainable Development. Journal of Contemporary Issues in Education, 2, 21-37. https://doi.org/10.20355/C5Z594

[103] Weckmüller, H., Barriocanal, C., Maneja, R., Boada, M. and Weckmüller, H. (2019) Factors Affecting Traditional Medicinal Plant Knowledge of the Waorani, Ecuador. Sustainability, 11, 4460. https://doi.org/10.3390/su11164460 